\title{
Manajemen Pembelajaran melalui Pendekatan BCCT dalam Meningkatkan Multiple intelligences Anak
}

\author{
Mustajab $^{1}$, Hasan Baharun ${ }^{2}{ }^{\bowtie}$, Lutfiatul Iltiqoiyah $^{3}$ \\ Pendidikan Agama Islalm, Institut Agama Islam Negeri Jember (1) \\ Manajemen Pendidikan Islam, Universitas Nurul Jadid, Paiton, Probolinggo (2) \\ Pendidikan Anak Usia Dini, Universitas Nurul Jadid, Paiton, Probolinggo (3) \\ DOI: $10.31004 /$ obsesi.v5i2.781
}

\begin{abstract}
Abstrak
Kecerdasan majemuk sangat penting untuk dikembangkan pada anak didik, sehingga diperlukan pendekatan yang tepat guna untuk mencapai target tersebut, salah satunya adalah pendekatan BCCT (Beyond Centre And Circle Time). Penelitian ini bertujuan untuk menganalisis dan memahami tentang manajemen pembelajaran pada anak usia dini melalui pendekatan BCCT (beyond centre and circle time) dalam meningkatkan multiple intelligences anak. Penelitian ini menggunakan metode kualitatif jenis studi kasus. Penelitian ini dilakukan pada siswa di TK Namira School dan TK Islam Terpadu Permata, Kraksaan, Probolinggo, Jawa Timur. Hasil penelitian menunjukkan bahwa Dalam menerapkan BCCT guna meningkatkan multiple intelligences anak, diperlukan pengelolaan yang terencana, terstruktur dan sistematis. Melalui perencanaan desain pembelajaran, pelaksanaan pembelajaran dan evaluasi pembelajaran yang sistemik, multiple intelligences anak dapat dikembangkan dengan baik.
\end{abstract}

Kata Kunci: kecerdasan majemuk; manajemen pembelajaran; pendekatan bcct.

\begin{abstract}
Multiple intelligence is very important to be developed in students, so an appropriate approach is needed to achieve this target, one of which is the BCCT (Beyond Center And Circle Time) approach. This study aims to analyze and understand learning management in early childhood through the BCCT (beyond center and circle time) approach in improving children's multiple intelligences. This research uses a qualitative method of case study type. This research was conducted on students at TK Namira School and TK Islam Terpadu Permata, Kraksaan, Probolinggo, East Java. The results show that in applying BCCT to improve children's multiple intelligences, a planned, structured and systematic management is needed. Through planning the learning design, implementing learning, and evaluating systemic learning, the multiple intelligences of children can be developed properly.
\end{abstract}

Keywords: multiple intelligences; learning management; bcct approach

Copyright (c) 2020 Mustajab, Hasan Baharun, Lutfiatul Iltiqoiyah

$\square$ Corresponding author :

Email Address : ha54nbaharun@gmail.com (Probolinggo Jawa Timur, Indonesia)

Received 21 September 2020, Accepted 15 November 2020, Published 19 November 2020 


\section{PENDAHULUAN}

Pengelolaan pembelajaran sangat dibutuhkan dalam rangka mengefektifkan pembelajaran, khususnya pada pembelajaran di lembaga Pendidikan Anak Usia Dini (PAUD) (Rohmat, 2017). Manajemen penyelenggaraan pendidikan berkaitan dengan tata laksana dan kelola lembaga (Azeez, 2016), berkaitan dengan pengelola administrasi, pengaturan, atau penataan kegiatan di lembaga (Larson et al., 2018). Manajemen sangat berperan penting dalam sebuah PAUD karena keberhasilan sebuah PAUD tidak lepas dari manajemen yang baik (Suharni, 2019).

Dalam aktivitas pendidikan anak usia dini, bukan hanya untuk memberikan pengalaman belajar kognitif kepada anak (Yalda Delgoshaeia, 2012), tetapi yang lebih penting berfungsi untuk mengoptimalkan perkembangan otak atau syaraf (Nasution et al., 2019). Anak usia dini merupakan periode awal, di mana pada masa ini pertumbuhan dan perkembangannya harus mendapatkan perhatian yang serius (Sari, 2019) (Alfina \& Anwar, 2020). Pada masa ini menjadi dasar dalam kehidupan anak untuk pengembangan selanjutnya (Trenggonowati, 2018). Pada masa ini pula, periode perkembangannya disebut periode emas (golden ages) (Suharti, 2018).

Pendidikan anak usia dini seharusnya juga mencakup seluruh proses stimulus psikososial dan tidak terbatas pada proses pembelajaran yang terjadi dalam lembaga pendidikan. Pendidikan anak usia dini dapat berlangsung kapan saja dan di mana saja, seperti berlangsungnya interaksi manusia yang terjadi di dalam keluarga, teman sebaya, dan hubungan kemasyarakatan (Bustami, Murniati, 2012).

Proses pembelajaran yang baik untuk anak usia dini sebaiknya menyesuaikan dengan kebutuhan dan perkembangan anak. Pembelajaran yang dapat dikembangkan pada kegaitan pembelajaran pendidikan anak usia dini adalah metode sentra dan lingkaran yang diadopsi dari pendekatan BCCT (Beyond Centre and Circle Time). Beyond Centers and Circles Time (BCCT) merupakan pendekatan pembelajaran yang berpusat pada anak didik, di mana aktivitas pembelajarannya berpusat pada sentra main dan dalam aktivitas lingkaran. Pembelajaran berbasis sentra merupakan pusat kegiatan bermain anak yang diharapkan mampu mengembangkan semua potensi dan perkembangan sesuai dengan tahapan usianya melalui stimulasi terpadu (Hasanaha \& Harmawati, 2020).

BCCT (Beyond Centre and Circle Time) dipercaya sebagai desain pembelajaran yang efektif bagi anak usia dini, terbukti dari statement para peneliti melalui hasil kajiannya di beberapa lembaga pendidikan. Hamzah (2016) dalam penelitiannya mengemukakna bahwa BCCT mampu menciptakan pembelaran yang menyenangkan (Joyfull Learning) dan penuh makna, pembelajaran tidak membosankan, apresiatif dan dinamis. Anak mampu mengkonstruk pengetahuan dan pengalamannya sendiri dan menjadi lebih mandiri. Iswantiningtyas \& Wulansari (2019) menyampaikan bahwa Melalui model pembelajaran BCCT (Beyond Centers and Circle Time), pendidikan karakter dapat ditanamkan pada anak usia dini dengan tepat, begitu juga dengan Ma'rifah A \& Muthmainnah (2015) yang mengatakan bahwa melalui metode BCCT dalam pengembangan nilai moral, maka tujuan pendidikan karakter dapat tercapai.

Model Pembelajaran BCCT yang menggunakan sentra-sentra, sudut-sudut, area-area bertujuan untuk membawa anak pada pengalaman bereksplorasi dan berinteraksi dengan orang lain dan lingkungan sekitar (Patintingan, 2017). Dalam pelaksanaannya disesuaikan dengan tahapan perkembangan anak. Pendekatan ini menunjukkan tentang pentingnya bermain peran, bermain sensorimotor, dan bermain pembangunan sampai pada kemampuan keaksaraan, yang didesain menyenangkan dan mencerdaskan.

Multiple intelligences merupakan teori kecerdasan yang dikemukakan oleh Howard Gardner (Yildiz et al., 2020). Kecerdasan seseorang tidak bisa diukur dari hasil tes psikologi standar (Wilson, 2018), namun dapat dilihat dari kebiasaan seseorang terhadap dua hal. Pertama, kebiasaan seseorang dalam menyelesaikan masalahnya sendiri (problem solving) (Baharun \& Adhimah, 2019). Kedua, kebiasaan seseorang dalam menciptakan produk-produk 
baru yang punya nilai budaya (creativity). Setiap anak punya kecenderungan kecenderungan kecerdasan dari sembilan kecerdasan, yaitu cerdas bahasa (linguistik) (Ayasrah \& Aljarrah, 2020), cerdas matematis-logis (kognitif), cerdas gambar dan ruang (visual-spasial) (Keklik, 2020)(Şener \& Çokçalışkan, 2018), cerdas musik, cerdas gerak (kinestetis), cerdas bergaul (interpersonal) (Sary, 2018), cerdas diri (intrapersonal) (Winarti et al., 2019), cerdas alam (Hanafin, 2014).

Hasil observasi awal di lapangan menunjukkan bahwa penyelengaraan pembelajaran anak usia dini masih belum sepenuhnya mengacu pada tahap-tahap perkembangan dan pertumbuhan anak, khususnya di TK Namira School dan TK Islam Terpadu Permata, Kraksaan, Probolinggo, sebagai obyek penelitian ini. Pada umumnya penyelengaraan pembelajarannya difokuskan pada peningkatan kemampuan akademik, baik dalam hal hafalan, membaca, menulis dan berhitung, yang prosesnya seringkali mengabaikan tahapan perkembangan dan pertumbuhan anak.

Pelaksanaan kegiatan pembelajarannya masih melupakan unsur bermain yang menjadi salah satu prinsip pendidikan anak usia dini termasuk Taman Kanak-Kanak. Kegiatan tersebut digantikan pada proses pembelajaran yang berorientasi pada aspek akademik, dengan artian bahwa kegiatan anak pada kedua lembaga tersebut lebih berfokus pada bagaimana anak belajar membaca, menulis dan berhitung dengan mengikuti metode yang diarahkan guru. Anak tidak diberi kebebasan untuk memilih kegiatan yang sesuai dengan minat dan kemampuan anak (Fardiah et al., 2019). Bermain menjadi langka, asing bagi anak, bahkan terkadang menjadi reward atas perilaku dan kompetensi anak yang sesuai dengan ekspektasi gurunya.

Hal inilah yang menjadi dasar ketertarikan peneliti untuk meneliti tentang desain pembelajaran yang dilakukan oleh TK Namira School dan TK Islam Terpadu Permata, Kraksaan, Probolinggo setelah menganalisis aspek pembelajaran yang selama ini dilakukan, baik analisis yang dilakukan oleh internal sekolah maupun eksternal sekolah. Paradigma pembelajaran pada kedua lembaga tersebut kemudian direkonstruksi dengan prinsip continuous improvement melalui implementasi BCCT (Beyond Centre and Circle Time) dalam kegiatan pembelajarannya.

Sedangkan penelitian tentang multiple intelligences dalam aktivitas pembelajaran juga banyak dilakukan oleh para peneliti, diantaranya; Aryani et al. (2014) yang mengatakan bahwa multiple intelligences merupakan suatu kemampuan untuk memecahkan masalahmasalah yang dihadapi dalam kehidupan. Legowo (2017) mengatakan bahwa pentingnya stimulasi multiple intelligences secara massif, intensif, dan berkelanjutan, agar tujuan pembelajaran dapat tercapai dengan baik. Rofiah (2016) menambahkan, melalui optimalisasi atau mengembangkan multiple intelligences, pembelajaran akan lebih efektif. Ardimen (2016) menuturkan bahwa Pembelajaran Integratif Berbasis Games dapat meningkatkan Multiple Intelligence siswa melalui bimbingan intensif guru.

Pembelajaran yang berorientasi pada multiple intelligences merupakan ikhtiar untuk memberikan pengalaman belajar kepada peserta didik, yang dirancang selaras dengan kebutuhan, gaya belajar, kognisi, dan inteligensi siswa. Pendekatan pembelajaran penstimulasian multiple intelligences mengasumsikan bahwa setiap anak cerdas, namun kecerdasan mereka bervariasi (Zamroni, 2020). Pendekatan pembelajaran multiple intelligences diharapkan dapat memfasilitasi varian inteligensi dan gaya belajar setiap siswa, sehingga mereka dapat senang dalam belajar dan mencapai prestasi optimal (Legowo, 2017).

Berdasarkan penelitian tersebut di atas, maka peneliti tertarik untuk menganalisis tentang pendekatan BCCT (Beyond Centre and Circle Time) dalam meningkatkan multiple intelligences anak usia dini, sehingga akan menjadi penelitian yang menarik dan memiliki kebaruan, yang berimplikasi pada diversifikasi keilmuan tentang desain pembelajaran yang efektif dalam mengembangkan potensi anak. Peneliti dalam hal ini memfokuskan kajiannya pada implementasi manajemen pembelajaran melalui pendekatan BCCT (Beyond Centre And 
Circle Time) dalam meningkatkan multiple intelligences anak di TK Namira School dan TK Islam Terpadu Permata, Kraksaan, Probolinggo.

\section{METODOLOGI}

Penelitian ini dilakukan pada dua lembaga Pendidikan Taman Kanak-Kanak, yaitu TK Namira School dan TK Islam Terpadu Permata, Kraksaan, Probolinggo, dengan menggunakan metode kualitatif jenis studi kasus, yang dilakukan secara terencana dan sistemati selama tiga bulan. Peneliti memilih dua lembaga TK tersebut karena berdasarkan hasil observsi awal penelitian, kedua lembaga tersebut sering melakukan inovasi pembelajaran untuk membangkitkan motivasi dan minat belajar anak. Di samping itu, kedua lembaga tersebut juga menerapkan pendekatan BCCT (Beyond Centre and Circle Time) dalam kegiatan pembelajarannya, yang mana ditujukan untuk meningkatkan multiple intelligences anak.

Informan dalam penelitian ini adalah kepala sekolah dan dewan guru yang diambil dengan pendekatan purposive sampling. Untuk mendapatkan gambaran tentang manajemen pembelajaran BCCT terhadap peningkatan multiple intelligences anak pada kedua lembaga tersebut, peneliti menggunakan wawancara mendalam tentang kegiatan pembelajaran melalui pendekatan BCCT dan multiple intelligences. Kemudian, peneliti juga melakukan observasi dan dokumentasi terhadap berbagai kegiatan yang dilakukan oleh guru dan siswa sesuai dengan tema penelitian, yaitu pendekatan BCCT dan multiple intelligences.

Analisis datanya dilakukan secara sirkuler, yang dimulai dari data display secara keseluruhan dari hasil wawancara, observasi dan dokumentasi yang diperoleh selama di lapangan. Kemudian peneliti melakukan data reduction, yaitu pemilahan dan pemilihan data yang telah terkumpul sesuai dengan tema yang telah ditentukan, sehingga akan didapatkan sebuah data yang tersusun secara sistematis sesuai dengan focus penelitian. Dari temuan penelitian sementara tersebut, kemudian diakhiri dengan penarikan kesimpulan penelitian, sebagai sebuah temuan penelitian.

\section{HASIL DAN PEMBAHASAN}

Hasil penelitian menunjukkan bahwa manajemen pembelajaran pada anak usia dini dengan menggunakan metode BCCT ( beyond centre and circle time) dalam meninggkatkan multiple intellegences anak di Taman Kanak-Kanak (TK) Namira School dan TKIT Permata, Kraksaan, Probolnggo, sebagai berikut;

\section{Perencanaan Pembelajaran BCCT dalam Meningkatkan Multiple intelligences Anak}

Maghfirah (2020) selalu guru TK Namira School mengatakan bahwa perencanaan pembelajaran merupakan hasil dari proses berpikir secara rasional dan sistematis dalam menentukan sasaran dan tujuan yang akan dicapai oleh guru di lembaga ini.

Setiap lembaga pendidikan khususnya Pendidikan Anak Usia Dini mempunyai perencanaan pembelajaran, termasuk TK Namira School dan TK Islam Terpadu Permata. TK Namira School dan TKIT Permata menerapkan perencanaan pembelajaran atau disebut planing.

Fatmini (2020) sebagai kepala TKIT Permata mengatakan perencanaan pembelajaran mencakup perencanaan setiap tahun (PROTA), perencanaan tiap semester (PROMES), perencanaan tiap minggu (RKM), dan perencanaan tiap hari (RKH) serta penyiapan ragam main bagi tiap-tiap guru sentra. Namun jika dalam pertengahan semester terdapat kondisi yang memungkinkan untuk merubah tema, maka tema akan dirubah secara fleksibel sesuai dengan kondisi pada saat itu.

Maghfirah (2020) sebagai Kepala TK Namira School mengatakan bahwa perencanaan pembelajaran merupakan program umum yang harus disusun dalam merencanakan kegiatan pembelajaran untuk lembaga pendidikan. Dalam penyusunan program tahunan, guru berpedoman pada kalender pendidikan yang meliputi tema untuk satu tahun. Setelah 
membuat program tahunan, barulah membuat perencanaan semester, yakni penjabaran dari perencanaan tahunan yang lebih terperinci. Kemudian setelah membuat program semester, barulah bisa membuat rencana kegiatan mingguan yang lebih spesifik, yakni penjabaran dari program semester yang dilaksanakan dalam satu minggu. Terakhir adalah membuat rencana kegiatan harian yang meru pakan hasil dari penjabaran rencana kegiatan mingguan, yang akan dilaksanakan dalam setiap kegiatan pembelajaran secara bertahap. Jadi, setiap kegiatan belajar sesuai dengan rencana pembelajaran yang telah dibuat oleh pendidik sesuai dengan sentra masing-masing. Kegiatan perencanaan tersebut dapat digambarkan sebagai berikut;

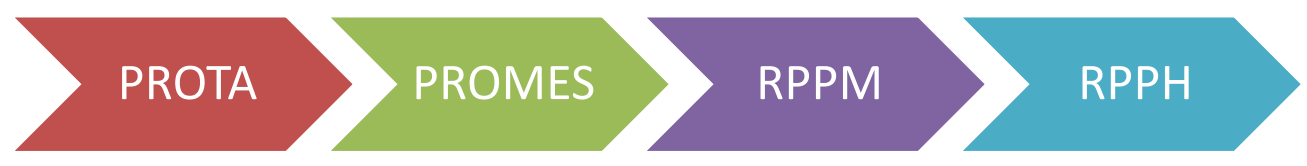

Gambar 1.1: Alur perencanaan Pembelajaran

Gambar 1.1 menunjukkan bahwa pembuatan perencanaan pada kedua lembaga pendidikan tersebut dilakukan secara terencana, terstruktur dan sistematis, yaitu waka bidang kurikulum menyiapkan format lesson plan, yang meliputi perencanaan tahunan, perencanaan semester, RPPM dan RKH. Selanjutnya, pendidik membuat rencana pembelajaran, kemudian dikonsultasikan kepada bagian kurikulum dan kepala sekolah untuk ditandatangani sebagai persetujuan dari pengelola yang mempunyai kompetensi dalam bidang psikologi dan Pendidikan Anak Usia Dini. Selanjutnya, pendidik bisa menjalankan rencana pembelajaran yang telah dibuatnya.

\section{Pelaksanaan Pembelajaran BCCT dalam meningkatkan Multiple Intelligences Anak}

Proses pembelajaran yang diterapkan TK Namira School dan TKIT Permata adalah belajar sambil bermain (learning with fun). Anak dapat belajar dengan baik, apabila dalam kondisi yang menyenangkan, yakni dengan cara bermain dan mengalaminya sendiri. Pembelajaran dapat dilakukan dalam 10 sentra yakni, sentra persiapan ABC, sentra persiapan 123 , sentra peran mikro, sentra peran makro, sentra alam, sentra memasak, sentra seni, sentra balok, sentra olah tubuh, dan sentra ibadah.

Maghfirah (2020) sebagai guru TK Namira School mengatakan bahwa pelaksanaan pembelajaran dimulai dari pukul 07.00-11.00 WIB untuk hari Senin sampai hari Kamis. Sedangkan hari Jumat dan Sabtu dimulai pukul 07.15-10.00 WIB. Fatmini (2020) sebagai guru TK Islam Terpadu Permata menjelaskan bahwa proses pembelajaran dilaksanakan mulai hari senin sampai hari sabtu, dengan ketentuan jam dari 07.00-11.00 WIB. Untuk hari Jumat dan Sabtu berbeda dengan hari lainnya, karena hari yang lebih pendek dimulai dari jam 07.1510.00 WIB.

Adapun proses pelaksanaan pembelajaran pada TK Namira School dan TK Islam Terpadu Permata, Kraksaan, Probolinggo secara garis besar mengacu pada tujuh tahapan, yakni kegiatan pembukaan, kegiatan shalat, mentoring dan tahfidz, qira'ati, istirahat dan makan, kegiatan inti/sentra, dan kegiatan penutup. Adapun lebih jelasnya adalah sebagai berikut:

Pertama, Kegiatan pembukaan. Kegiatan pembukaan ini mulai pukul 07.15-07.25 WIB. Adapun kegiatannya meliputi, salam dari guru, berdoa bersama yang dipimpin oleh salah satu diantara peserta didik. Adapun doanya mencakup membaca dua kalimat syahadat, doa mau belajar, doa mohon kecerdasan, membaca surat Al-Fatihah, ikrar dan asmaul husna yang semuanya itu dilakukan secara bersama-sama. Kegiatan selama pembukaan akan melatih anak dalam meningkatkan multiple intelligences, yaitu Kecerdasan linguistik

Kedua, Kegiatan shalat Dhuha. Shalat Dhuha berjamaah dilakukan mulai pukul 07.2507.55 WIB dan dilanjutkan dengan dzikir bersama dengan membaca; istighfar, tasbih, tahmid, takbir, dan tahlil. Adapun perlengkapan yang digunakan seperti ruang kelas, sajadah, imam 
dan makmum. Pada kegiatan shalat dhuha kecerdasan dari delapan kecerdasan, yaitu cerdas bahasa (linguistik) dan cerdas kinestetik.

Ketiga, Mentoring Tahfidz dan Qira'ati. Mentoring dan tahfidz ini dilaksanakan mulai pukul 07.45-08.15 WIB. Program mentoring yaitu hafalan surat-surat pendek dan hadits, di mana disesuaikan dengan kemampuan kelas. Hadits di sini berganti-ganti sesuai dengan kemampuan kelas. Beberapa Hadits yang harus dihafalkan yakni Hadits tentang larangan membenci, Hadits tentang ridho Allah bersama ridho orang tua, dan lain-lain. Setelah menghafalkan beberapa Hadits yang ditentukan, selanjutnya adalah doa. Beberapa doa yang dibaca disesuaikan dengan kemampuan kelas, antara lain doa turun hujan, doa ketika mendengar petir, dan lain- lain. Kegiatan Akhlak meliputi senang mencium tangan kepada siapapun, senang melakukan gerakan mencium tangan kepada orang lain. Kegiatan Aqidah meliputi mempercayai nama-nama Allah yang Indah/baik, meliputi Al Mughniy, Ar Razzaqu, dan seterusnya yang dilaksanakan secara serentak oleh anak-anak.

Untuk kegiatan tahfidz, masing-masing anak berbeda sesuai kemampuan hafalannya, sehingga untuk satu kelas, setiap anak memiliki guru tahfidz yang berbeda-beda. Mereka melakukan moving sendiri atau berpindah kelas untuk mencari guru tahfidznya. Metode yang digunakan dalam pembelajaran tahfidz ini adalah klasikal individual, di mana anak maju satu, dua atau tiga orang kepada guru, kemudian guru menyimak dan membenarkan jika ada yang salah. Beberapa perlengkapan yang dibutuhkan, antara lain buku panduantahfidz dan mentoring untuk guru musafahah antar guru dan anak.

Kegiatan qira'ati ini dilaksanakan mulai 08.15- 09.00 WIB. Kegiatan diawali dengan membaca do'a belajar al-Qur'an, selanjutnya belajar qira'ati secara individual atau sendirisendiri menghadap guru, atau disebut sistem sorogan. Sistem sorogan yakni sebuah sistem belajar dengan cara anak bergiliran maju satu persatu ke pendidik untuk mengaji. Anak-anak secara bergantian maju satu persatu di depan guru qira'ati. Guru qira'ati ini juga termasuk guru kelas. Adapun alat yang digunakan seperti Standar Operasional Prosedur (SOP) qira'ati, buku qira'ati, peraga, buku prestasi, dan rekap nilai. Pada kegiatan Mentoring Tahfidz dan Qira'ati kecerdasan dari delapan kecerdasan, yaitu cerdas bahasa (linguistik).

Keempat, Istirahat dan makan. Istirahat dan makan dilaksanakan mulai pukul 09.0009.30 WIB. Kegiatan istirahat dimulai dengan bermain bebas, cuci tangan sebelum makan, makan bersama dengan diawali berdoa, membaca doa setelah makan dan merapikan tempat makan. Perlengkapan yang dibutuhkan antara lain alat bermain indoor dan outdoor, SOP (Standar Operasional Prosedur) makan, wastafel, sabun, lap tangan, bekal makanan anak (bawa sendiri dari rumah) dan kadang beberapa kali diberi bekal dari sekolah, serta perlengkapan makan dan minum. kegiatan istirahat dan makan juga mencakup kecerdasan dari delapan kecerdasan, yaitu cerdas bahasa (linguistik) cerdas kinestetik.

Kelima, Kegiatan inti/sentra. Kegiatan inti/sentra berlangsung selama satu jam tiga puluh menit, yakni mulai pukul 09.30-11.00 WIB oleh guru sentra pada masing-masing kelas sentra. Pembelajaran di dalam sentra dilaksanakan melalui empat pijakan, yaitu pijakan lingkungan main, pijakan sebelum main, pijakan saat main, dan pijakan sesudah main. Pijakan lingkungan main meliputi tempat main, jumlah ragam main, kelas serta jumlah anak dalam satu kelas. Pijakan sebelum main meliputi salam, doa membaca basmallah, mengupas tema, membacakan aturan dan harapan main, meliputi perhatikan, pegangnya nanti, pilih teman, pilih mainan, mainkan, perlihatkan, rapikan, sayang guru dan teman. Pijakan saat main meliputi mengamati, memotivasi dan menilai (Khairun Nisa, 2020). Anak-anak berperan aktif, mereka seolah menjadi orang yang ada dalam permainan itu. Pijakan setelah main yaitu recalling, yakni evaluasi dan review, membaca doa penutup majelis dan doa sebelum makan.

Media yang digunakan disesuaikan dengan sentra, yakni meliputi media visual (sebuah media yang berhubungan dengan penglihatan seperti gambar), media audio (berhubungan dengan suara seperti radio) dan media audio visual (berhubungan dengan penglihatan dan suara seperti televisi, video animasi). Selain itu, ada media APE (Alat Perlengkapan Edukatif) baik indoor maupun outdoor, seperti puzzle, balok, boneka, kotak 
alphabet, kartu bilangan, kartu pasangan, papan titian, jungkat-jungkit, bola dunia, perosotan, ayunan, bola basket, golf, dan bola tendang.

Metode yang dilakukan dalam pembelajaran sentra ini biasanya diawali dengan metode ceramah (bercerita), dilanjutkan demonstrasi yakni guru mencontohkan kegiatan apa yang akan dilakukan, dan kemudian anak langsung praktek sesuai dengan yang diajarkan dan targetkan oleh guru. Metode lain yang digunakan seperti metode bercerita, metode bercakap-cakap (dialog), metode praktek langsung, metode tanya jawab, metode karyawisata, metode eksperimen, metode pemberian tugas, dan metode sosio drama (peran). Selain itu, anak juga biasa untuk mengerjakan tugas atau menyelesaikan masalah dengan permainan yang ada pada masing-masing sentra. Seperti menyelesaikan perhitungan koin sampai bilangan 25, menulis angka, menyusun puzzle, memasukkan air ke dalam plastik seperti bentuk es batu, membuat mobil-mobilan dengan kardus, dan seterusnya.

Dalam memaksimalkan pembelajaran sentra, guru memberikan banyak stimulus, di antaranya memperbanyak ragam main pada tiap-tiap sentra. Di mana ragam main pada setiap sentra sekurang kurangnya terdiri dari tiga jenis ragam main (Gambar 1). Misalkan, ragam main pada sentra persiapan ABC antara lain membaca cerita, menulis pengalaman pribadi, menyusun puzzle huruf. Pada sentra persiapan 123 seperti menulis angka, puzzle angka $(1,2$, $3,4,5, \ldots)$, menghitung koin sampai 25 biji yang kemudian dihitung bersama bunda untuk melihat kebenarannya, menghitung penjumlahan angka, dan menghitung pengurangan angka. Sentra peran mikro terdapat enam ragam main, yakni taman bermain, pantai marina, dealer mobil, rumah keluarga, penjual buah dan sayur, serta Kebun Binatang Mangkang. Sedangkan sentra peran makro meliputi enam ragam main, yakni Rumah (kasur, meja makan, uang, perlengkapan rumah, dapur), pantai (tempat penjual tiket dan pantainya), penjual mainan mobil, penjual mainan boneka, penjual makanan, penjual cindera mata.

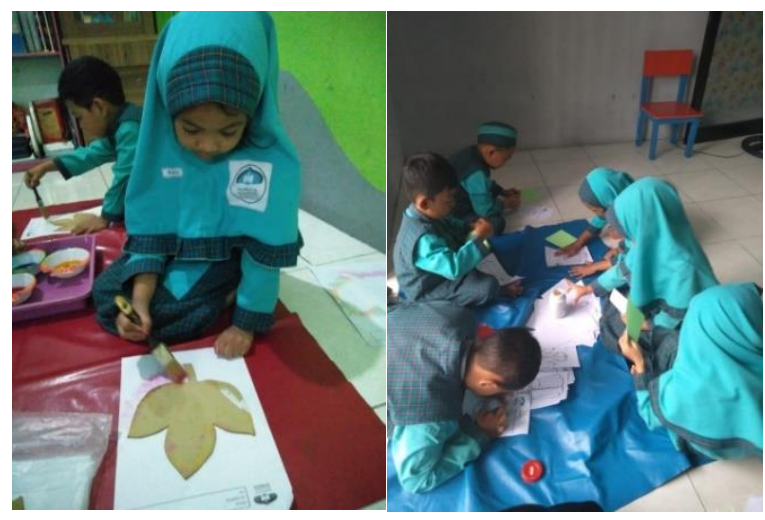

\section{Gambar 1: Kegiatan pembelajaran sentra}

Adapun sentra alam terdapat lima ragam main, yakni menggambar bungam mobil, mewarnai bungam mobil dengan crayon dan cat, membuat mobil dengan kardus, memasukkan air ke dalam es plastik dan mengikatnya dengan tali agar tidak tumpah, memilih barang/benda yang tenggelam da ntidak tenggelam dalam air. Sentra memasak guru menyiapkan empat ragam main dan mencontohkannya. Adapun empat ragam main meliputi kegiatan memotong wortel, kegiatan memotong kubis, menguleg bumbu (bawang putih, garam), pengadonan dengan tepung (bakwan). Selanjutnya, penggorengan dilakukan oleh guru, dan anak mencatat bahan-bahan masakan yang ditulis oleh guru. Pada sentra balok, anak di lihatkan dengan berbagai bentuk rumah dan pantai, kemudian guru menyediakan berbagai bentuk balok, anak dibebaskan membuat rumah dengan kisi-kisi ada rumah, taman dan dari belakang rumah terlihat sebuah pantai.

Lebih lanjut, pada sentra seni terdapat tiga ragam main, yakni menghias perahu kertas dengan kertas warna, mewarnai gambar pantai yang ada perahunya, dan menempelkan gambar perahu dan sinar matahari pada daerah di sekitar pantai dengan berbagai macam 
kertas warna yang berbentuk. Sentra ibadah terdapat lima ragam main, yakni mengurutkan gambar gerakan shalat, mengurutkan gambar wudlu, mengurutkan huruf hijaiyah, puzzle hijaiyah, menjodohkan nama shalat dengan jumlah rakaatnya. Selanjutnya pada sentra olah tubuh, beberapa permainan yang dilakukan dalam sentra olah tubuh antara lain; bermain bola basket (memasukkan bola dalam keranjang), naik turun tangga tali, bermain dengan simpai(hola-hop), membungkukkan badan dalam memasuki terowongan, berjalan di atas papan titian, menaiki tangga majemuk, memanjat bola dunia, bermain balling ball, bermain loncat tali, bermain golf, bermain bola kaki, bulu tangkis, menari sesuai irama musik, bermain engklek (patahan), memantulkan atau melambungkan bola dan bertepuk tangan.

Keenam, Kegiatan penutup. Kegiatan penutup ini meliputi bernyanyi dan tepuk, berdoa sesudah makan, doa penutup majelis, doa kedua orang tua, doa keluar kelas, membaca surat Al-'Ashr, mengingat pesan Ibu guru, menerima informasi, dan salam. Untuk waktunya diambilkan 15 menit terakhir dari pembelajaran sentra. Hari Jumat dan Sabtu tidak ada sentra, karena hari itu digunakan untuk melakukan berbagai kegiatan pengembangan seni dan kreativitas yang merupakan upaya tindak lanjut setelah pembelajaran sentra kegiatan. Pada hari Jumat dijadwalkan periksa kesehatan dan infaqbagi anak, langkah-langkahnya sebagai berikut: anak melakukan infaq dengan memberi uang kepada Bunda (guru kelas) dan Bunda menulis di dalam buku catatan infaq, setelah itu cek kuku, cek gigi, cek telinga dan cek rambut. Uniknya sang Bunda melakukannya dengan kasih sayang, satu persatu anak maju dan dicek langsung oleh masing-masing guru kelas.

Pada hari Sabtunya dilakukan senam bersama dan kegiatan intrakurikuler. Kegiatan intrakurikuler merupakan kegiatan yang dijadikan sebagai upaya tindak lanjut dari kegiatan sentra. Dalam intrakurikuler disediakan lima macam pengembangan diri, meliputi menari, simple sains, logika matematika, menggambar dan mewarnai dan fun game, di mana anak harus memilih satu di antara kelima pengembangan diri tersebut.

Selanjutnya, diadakan acara parenting bagi wali murid, yang mana hal ini merupakan kepedulian dan dukungan wali murid terhadap program sekolah. Parenting, yakni acara orang tua atau wali murid peserta didik yang dilakukan setiap hari Sabtu mulai pukul 08.0010.00 WIB. Tujuannya adalah agar pemahaman orang tua kepada anak sama dengan pendidikan di TK. Selain itu, juga agar tidak terjadi perbedaan pemahaman sang anak, sehingga anakpun tidak akan bingung mana yang harus dilakukan dan mana yang tidak harus dilakukan, karena adanya kesesuaian dengan sekolah. Selanjutnya, anak-anak juga diajak bermain keluar untuk berkaryawisata, kemudian diajak outbond di luar untuk melatih kecerdasan kinestetis anak. Selain itu, TK Namira School dan TK Islam Terpadu Permata, Kraksaan, Probolinggo juga ikut merayakan kegiatan pada hari-hari besar seperti hari Kemerdekaan Indonesia, hari ibu, hari kartini, dan hari besar lainnya yang diikuti oleh anakanak dan orangtua. Jadi, kegiatan mereka tidak hanya di dalam kelas tetapi juga diajak bereksplorasi di luar kelas. Kegiatan penutup di sini juga mencakup semua kecerdasan, diantaranya kecerdasan linguistik, intelegensi logis-matematis intelegensi musik, intelegensi kinestetik, intelegensi visual-spasial, intelegensi interpersonal, intelegensi intrapersonal dan intelegensi naturalis.

\section{Evaluasi Pembelajaran BCCT dalam Meningkatkan Multiple intelligences Anak}

Evaluasi pembelajaran dilaksanakan oleh TK Namira School dan TK Islam Terpadu Permata, Kraksaan, Probolinggo. Menurut Fatmini (2020), evaluasi terhadap penggunaan pendekatan BCCT (beyond centers and circle time) dilakukan setiap bulan pada hari Rabu pekan ke 3 dan ke 4 yang biasa disebut KKG (Kelompok Kerja Guru). Evaluasi ini dilakukan bersama-sama untuk membahas hal-hal yang dialami selama pembelajaran di kelas, seluruh keluhan dari guru bisa diungkapkan semuanya, sehingga para guru dan kepala sekolah beserta jajarannya dapat membuat solusi atas persetujuan bersama. 
Fatmini (2020) mengatakan evaluasi pembelajaran dilakukan dari mulai anak datang sampai anak pulang ke rumah masing-masing. Misalnya, apakah anak-anak mau ditinggal orang tuanya hingga akhir waktu penjemputan, apakah perkembangan anak sudah muncul dan aspek-aspek lain yang perlu dievaluasi.

Dalam melakukan evaluasi, pendidik membuat catatan anekdot tersendiri. Selain itu, dalam setiap harinya pendidik mengisi penilaian harian pada anak saat pembelajaran tahfidz dengan evaluasi buku prestasi tahfidz, pembelajaran qira'ati dengan evaluasi buku prestasi qira'ati dan penilaian pembelajaran sentra dengan lembar penilaian pembelajaran sentra. Metode yang digunakan dalam melakukan evaluasi adalah metode observasi atau pengamatan, yaitu dilakukan dengan mengamati perilaku dan aktivitas anak dalam suatu waktu atau kegiatan.

Evaluasi mengenai perkembangan anak dilakukan sesuai dengan tingkat perkembangan anak dari perkembangan moral, kognitif, sosial, serta emosional. Hasil evaluasi dicatat di format penilaian harian anak yang dibawa oleh masing- masing pendidik. Bentuk penilaian terbagi menjadi beberapa macam. Penilaian tahfidz dan qira'ati disediakan buku prestasi siswa TK Namir School dan TK Islam Terpadu Permata yang berisi mengenai hafalan surat-surat pendek anak, jilid anak, catatan perkembangan anak dan nilai hafalan anak yang ditandai dengan bintang. Semakin banyak bintang, maka nilai atau hafalan anak semakin baik, begitu sebaliknya. Adapun penilaian kegiatan sentra dicatat dalam format penilaian harian kegiatan sentra yang berisi mengenai kompetensi inti, kompetensi dasar, dan catatan perkembangan anak yang di nilai dengan tanda bintang (berkembang sangat baik), tanda check list (berkembang sesuai target), tanda $\mathrm{O}$ (mulai berkembang), dan tanda $\mathrm{O}$ (perlu bimbingan). Dalam bentuk penilaian bisa berupa bilangan, huruf, tanda, dan ada pula yang berbentuk uraian.

\section{Pembahasan}

Perencanaan pembelajaran dipahami sebagai aktivitas mendesain suatu tindakan yang akan dilakukan oleh guru dalam kegiatan pembelajarannya (Saufi \& Hambali, 2019), sehingga tujuan, materi, metode/strategi/pendekatan, teknik evaluasi menjadi jelas, terukur dan sistematis (Hanifah \& Amaliah, 2018). Manajemen PAUD menjadi sangat penting diperhatikan ketika melihat kenyataan bahwa daya imajinasi, krativitas, inovatif dan proaktif lulusannya berbeda secara signifikan dengan tidak melalui pendidikan anak usia dini. Hal ini penting karena era global yang penuh dengan persaingan, diperlukan SDM berkualitas dengan daya saing yang sangat tinggi agar kita tidak terus menerus tertinggal (Babuta \& Rahmat, 2019). Untuk itu, perlu SDM berkualitas guna membenahi dan meningkatkan manajemen PAUD (Yuliyati, 2020), secara khusus terkait dengan pembelajaran PAUD yang meliputi proses perencanaa, pengorganisasian, pelaksanaan dan penilaian (Rofiq, 2017) (Elfrida Ita, 2018). Aspek perkembangan anak salah satunya adalah aspek perkembangan kognitif yang memegang peranan penting dalam perkembangan Anak Usia Dini. Hal ini dikarenakan kognitif erat kaitannya dengan proses berfikir.

PAUD berfungsi membina, menumbuhkan, dan mengembangkan seluruh potensi yang dimiliki anak pada usia dini secara optimal sehingga terbentuk perilaku dan kemampuan dasar sesuai dengan tahap perkembangannya agar memiliki kesiapan untuk memasuki pendidikan selanjutnya. Hal ini didasarkan akan pentingnya pendidikan untuk anak usia dini dalam menyiapkan manusia Indonesia seutuhnya, membangun masa depan anak-anak dan masyarakat Indonesia seluruhnya (Kristiawan \& Muhammad, 2017).

Program pendidikan PAUD ditujukan untuk memberikan fasilitas pendidikan yang sesuai bagi anak, agar anak pada saatnya memiliki kesiapan baik secarafisik, mental maupun perkembangan kognitifnya dalam rangka memasuki pendidikan leboih lanjut. Idealnya pada usia pra sekolah, perkembangan kognitif anak dikembangkan secara maksimal yang dilakukan melalui model pembelajaran beyond centers and circle times (BCCT). Model BCCT atau sentra ini proses pembelajaran berpusat di sentra main dan saat dalam lingkaran. Sesaat 
sebelum anak bermain, anak oleh gutu diklasifikasikan dalam bentuk melingkar mengelilingi guru. Dalam posisi lingkaran inilah, guru melakukan kegiatan pendahuluan pembelajaran mengucapkan salam, mengabsen, menanyakan kabar anak, berdo'a, menyampaikan tema pembelajaran dan tujuan pembelajaran. Kegiatan ini dilakukan secara menyenangkan karena diselingi dengan lagu, gerak tari, senam, tepuk tangan dan lain-lain (Hamzah, 2016).

Pendekatan Beyond Centers and Circles Time (BCCT) memandang bermain sebagai media yang tepat dan satu-satunya media pembelajaran anak, karena di samping menyenangkan, bermain dalam setting pendidikan dapat menjadi media untuk berpikir aktif dan kreatif. Dalam BCCT ini, anak dirangsang untuk secara aktif melakukan kegiatan bermain sambil belajar di sentra-sentra pembelajaran. Adapun sentra dalam model ini, yakni : Sentra Imtaq (Iman dan Taqwa), Sentra Balok, Sentra Bermain Peran, Sentra Seni dan Kreativitas, Sentra Musik dan Olah Tubuh, Sentra Bahan Alam dan sentra yang lainnya. Pendidik lebih banyak berperan sebagai motivator dan fasilitator dengan memberikan pijakan-pijakan.

Pijakan yang diberikan sebelum dan sesudah anak bermain dilakukan dalam setting duduk melingkar sehingga dikenal dengan sebagai "Saat Lingkaran". Pijakan yang lainnya adalah pijakan lingkungan (setting dan keragaman lingkungan) dan pijakan pada setiap anak yang dilakukan selama anak bermain. Model pembelajaran ini tersedia guna mengembangkan potensi dan minat masing-masing anak. Kurikulum yang digunakan dalam pendekatan ini mendasarkan pada asumsi bahwa, anak belajar melalui bermain dengan bendabenda dan orang-orang di sekitarnya (lingkungan). Dalam bermain, anak berinteraksi dengan lingkungannya. Pengalaman bermain yang tepat dapat mengoptimalkan seluruh aspek perkembangan anak, baik fisik, kognisi, bahasa, maupun sosial anak. Ada tiga fungsi utama dalam metode BCCT, yaitu melejitkan kecerdasan anak, penanaman nilai-nilai dasar, dan pengembangan kemampuan dasar.

Pentingnya pengembangan multiple intellegences pada anak usia dini dengan melatih motorik (kinestetik), melatih mengolah angka logika atau akal sehat, mengolah kata atau kemampuan megolah kata baik secara lisan maupun tulisan, dapat berpikir secara logis dan kemampuan berkomunikasi antar teman. Salah satu komponen dalam pembelajaran adalah pemanfaatan berbagai macam strategi dan metode pembelajaran secara dinamis dan fleksibel (Darimi, 2016).

Konsep multiple intelligence sendiri dikembangkan oleh Howard Gardner yang menjelaskan bahwa kecerdasan (intelligence) merupakan kemampuan seorang individu dalam memecahkan masalah yang muncul dalam kehidupan nyata; kemampuan seorang individu melahirkan masalah baru untuk dipecahkan; serta kemampuan seorang individu menyiapkan atau menawarkan suatu layanan yang bermakna dalam kehidupan kultur tertentu. Gardner menjelaskan bahwa kecerdasan atau intelegensi ada 8 (delapan) macam yang merupakan potensi intelektual seseorang untuk dapat mengikuti proses pembelajaran (Tanju Gürkan, Çağlayan Dinçer, 2019). Kedepalan macam kecerdasan yang dimaksud yaitu sebagai berikut:

Pertama, kecerdasan linguistik (Linguistik intelligence), yakni kemampuan untuk berfikir dalam bentuk kata-kata dan menggunakan bahasa untuk mengekpresikan dan menghargai makna yang komplek, yang meliputi kemampuan membaca, mendengar, menulis, dan berbicara (Fitriani, 2018). Kedua, intelegensi logis-matematis (Logical matematich), yakni kemampuan dalam menghitung, mengukur dan mempertimbangkan proposisi dan hipotesis serta menyelesaikan operasi-operasi matematika. Ketiga, intelegensi Musik (Musical intelegence), yakni kecerdasan seseorang yang berhubungan dengan sensitivitas pada pola titik nada, melodi, ritme, dan nada. Musik adalah bahasa pendengaran yang menggunakan tiga komponen daskomar yaitu intonasi suara, irama dan warna nada yang memakai system symbol yang unik.

Keempat, Intelegensi kinestetik. Kinestetik adalah belajar melalui tindakan dan pengalaman melalui panca indera. Intelegensi kinestetik adalah kemampuan untuk menyatukan tubuh atau pikiran untuk menyempurnakan pementasan fisik. Dalam kehidupan 
sehari-hari dapat diamati pada actor, atlet atau penari, penemu, tukang emas, mekanik. Kelima, intelegensi Visual-Spasial, merupakan kemampuan yang memungkinkan memvisualisasikan infoomasi dan mensintesis data-data dan konsep- konsep ke dalam metavor visual. Keenam, intelegensi Interpersonal, yakni kemampuan untuk memahami dan berkomunikasi dengan orang lain dilihat dari perbedaan, temperamen, motivasi, dan kemampuan. Ketujuh, intelegensi Intrapersonal, yakni kemampuan seseorang untuk memahami diri sendiri dari keinginan, tujuan dan sistem emosional yang muncul secara nyata pada pekerjaannya. Kedelapan, intelegensi Naturalis, yakni kemampuan untuk mengenal flora dan fauna melakukan pemilahan-pemilahan utuh dalam dunia kealaman dan menggunakan kemampuan ini secara produktif misalnya untuk berburu, bertani, atau melakukan penelitian biologi (Sabriye Şener, 2018).

Adapun yang dimaksud dengan strategi pembelajaran berbasis multiple intelligence pada hakekatnya adalah upaya mengoptimalkan kecerdasan majemuk yang dimiliki setiap individu (anak didik) untuk mencapai kompetensi tertentu (Beceren, 2010). Melalui teori multiple intelligences memungkinkan guru mengembangkan strategi pembelajaran inovatif yang relatif baru dalam dunia pendidikan. Hal ini disebabkan karena tidak ada strategi pembelajaran yang efektif untuk semua anak didik, karena setiap anak didik memiliki kecenderungan kecerdasan yang berbeda (Delgoshaei \& Delavari, 2012).

Strategi pembelajaran berbasis multiple intelligence pada praktiknya adalah memacu kecerdasan yang menonjol pada diri anak didik seoptimal mungkin, dan berupaya mempertahankan kecerdasan lainnya pada standar minimal yang ditentukan. Terdapat dua tahapan yang perlu dilakukan dalam penerapan strategi pembelajaran berbasis multiple intelligence agar mendapatkan hasil yang optimal yaitu; pertama, memberdayakan semua jenis kecerdasan yang ada pada setiap mata pelajaran; kedua, mengoptimalkan pencapaian mata pelajaran tertentu berdasarkan kecerdasan yang menonjol pada masing-masing anak didik (Habibi et al., 2017).

\section{SIMPULAN}

Multiple intelligences dapat tercapai dengan baik apabila pendekatan BCCT dilakukan secara terencana, terstruktur dan sistematis. Rancangan pembelajaran yang disusun meliputi, rencana pembelajaran, pelaksanaan pembelajaran dan evaluasi pembelajaran. Lembaga pendidikan yang menjadi obyek penelitian ini telah menerapkan manajemen pembelajaran melalui pendekatan BCCT dalam meningkatkan multiple intelligences anak. Dilaksanakan secara terencana, terstruktur dan sistematis. Tentunya hasil penelitian ini tidak bisa digeneralisir untuk semua lembaga pendidikan, terkait manajemen pembelajaran pada anak usia dini melalui pendekatan BCCT, akan tetapi penelitian ini hanya tertuju pada lembaga pendidikan taman kanak-kanak yang memiliki latar dan karakteristik tertentu. Peneliti berharap akan muncul penelitian lanjutan tentang manajemen pembelajaran pada PAUD melalui pendekatan BCCT yang lebih komprehensif, sehingga mampu melengkapi keterbatasan penelitian.

\section{UCAPAN TERIMA KASIH}

Peneliti mengucapkan terima kasih tak terhingga kepada semua pihak yang telah membantu terselesaikannya penelitian ini dengan baik. Secara khusus, peneliti mengucapkan terima kasih kepada pimpinan dan dewan guru di TK Namira School dan TK Islam Terpadu Permata, Kraksaan, Probolinggo, Jawa Timur, yang telah membantu peneliti secara langsung maupun tidak langsung. Selanjutnya, peneliti juga mengucapkan terima kasih kepada Rektor IAIN Jember dan Universitas Nurul Jadid, Probolinggo, yang telah memberikan dukungan bagi terselesaikannya penelitian ini. 


\section{DAFTAR PUSTAKA}

Alfina, A., \& Anwar, R. N. (2020). Manajemen Sekolah Ramah Anak Paud Inklusi. Al-Tanzim: Jurnal Manajemen Pendidikan Islam, 4(1), 36-47. https://doi.org/10.33650/altanzim.v4i1.975

Ardimen. (2016). Pengembangan Multiple Intelligence Melalui Pembelajaran Integratif Berbasis Games. Jurnal Edukasi, 2(2), 107-129.

Aryani, A. D., Sudjito, D. N., \& Sudarmi, M. (2014). Model Pembelajaran Berdasarkan Teori Multiple Intellegence yang Dominan dalam Kelas pada Materi Tekanan. 6(2), 133-136.

Ayasrah, S. M., \& Aljarrah, A. H. (2020). The differences in multiple intelligences between the students of jordan university of science and technology. International Journal of Higher Education, 9(4), 35-45. https:// doi.org/10.5430/ijhe.v9n4p35

Azeez, A. T. A. (2016). Analysis of Management Practices in Lagos State Tertiary Institutions through Total Quality Management Structural Framework. Journal of Education and Practice, 7(8), 6-26.

Babuta, A. I., \& Rahmat, A. (2019). Peningkatan Kompetensi Pedagodik Guru melalui Pelaksanaan Supervisi Klinis dengan Teknik Kelompok. Al-Tanzim: Jurnal Manajemen Pendidikan Islam, 03(01), 1-28.

Baharun, H., \& Adhimah, S. (2019). Adversity Quotient: Complementary Intelligence in Establishing Mental Endurance Santri in Pesantren. Jurnal Ilmiah ISLAM FUTURA, 19(1), 128-143.

Beceren, B. Ö. (2010). Determining multiple intelligences pre-school children (4-6 age) in learning process. Procedia Social and Behavioral Sciences, 2(2), 2473-2480. https://doi.org/10.1016/j.sbspro.2010.03.356

Bustami, Murniati, C. Z. H. (2012). Manajemen Pendidikan Paud Al- Fath Sabang. Jurnal Administrasi Pendidikan, 1(2), 1-12.

Darimi, I. (2016). Diagnosis Kesulitan Belajar Siswa Dalam Pembelajaran Aktif Di Sekolah. JURNAL EDUKASI: Jurnal Bimbingan Konseling, 2(1), 30. https://doi.org/10.22373/je.v2i1.689

Delgoshaei, Y., \& Delavari, N. (2012). Applying multiple-intelligence approach to education and analyzing its impact on cognitive development of pre-school children. Procedia Social and Behavioral Sciences 32, 32(2010), 361-366. https://doi.org/10.1016/j.sbspro.2012.01.054

Elfrida Ita. (2018). Manajemen Pembelajaran Pendidikan Anak Usia Dini di TK Rutosoro Kecamatan Golewa Kabupaten Ngada Flores Nusa Tenggara Timur. Jurnal Dimensi Pendidikan Dan Pembelajaran, 6(1), 45-52.

Fardiah, F., Murwani, S., \& Dhieni, N. (2019). Meningkatkan Kemampuan Kognitif Anak Usia Dini melalui Pembelajaran Sains. Jurnal Obsesi : Jurnal Pendidikan Anak Usia Dini, 4(1), 133. https:// doi.org/10.31004/obsesi.v4i1.254

Fatmini. (2020). Interview.

Fitriani, A. F. J. Z. A. A. S. S. F. (2018). Improving Speaking Skills Using The Beyond Centers And Circle Time (BCCT) Technique. English Education Journal (EEJ), 9(3), 443-465.

Habibi, Y., Srifariyati, Hasan, H., \& Subhi, M. R. (2017). Strategi Pembelajaran Anak Usia Dini Berbasis Multiple Intelligence. Jurnal Madaniyah, 7(2), 237-260.

Hamzah, N. (2016). Pelaksanaan Pembelajaran BCCT Bagi Anak Usia Dini ;Study Pelaksanaan BCCT Di Tk Islam Mujahidin Pontianak. At-Turats: Jurnal Pemikiran Pendidikan Islam Journal, 10(2), 119-131.

Hanafin, J. (2014). Multiple Intelligences Theory, Action Research, and Teacher Professional Development: The Irish MI Project. 39(4).

Hanifah, H., \& Amaliah, F. (2018). Manajemen Pembelajaran Bagi Anak Usia Dini dalam Meningkatkan Kualitas Pembelajaran di Pos PAUD Dahlia 15. Jurnal Comm-Edu, 1(3), 24-29.

Hasanaha, N., \& Harmawati, D. (2020). Manajemen Pembelajaran Taman Kanak-Kanak Model 
Sentra dengan Pendekatan Beyond Centers And Circle Time ( BCCT ). Jurnal Ilmu Pendidikan, Keguruan, Dan Pembelajaran, 4(1), 30-33.

Iswantiningtyas, V., \& Wulansari, W. (2019). Penanaman Pendidikan Karakter pada Model Pembelajaran BCCT (Beyond Centers and Circle Time). Jurnal Obsesi : Jurnal Pendidikan Anak Usia Dini, 3(1), 110. https:// doi.org/10.31004/obsesi.v3i1.106

Keklik, I. (2020). Multiple Intelligences Profiles in Prospective Teachers. Education Reform Journal, 5(1), 27-44.

Khairun Nisa, S. (2020). Efektivitas Komunikasi Guru terhadap Motivasi Belajar Anak Usia Dini. Jurnal Pendidikan Anak Usia Dini, 5(1), 229-240. https:// doi.org/10.31004/obsesi.v5i1.534

Kristiawan, R., \& Muhammad. (2017). Pengelolaan Pembelajaran PAUD Dalam Mengembangkan Potensi Anak Usia Dini. JMKSP (Jurnal Manajemen, Kepemimpinan, Dan Supervisi Pendidikan), 2(1), 76-86.

Larson, K. E., Pas, E. T., Bradshaw, C. P., Rosenberg, M. S., \& Day-Vines, N. L. (2018). Examining how proactive management and culturally responsive teaching relate to student behavior: Implications for measurement and practice. School Psychology Review, 47(2), 153-166. https:// doi.org/10.17105/SPR-2017-0070.V47-2

Legowo, E. (2017a). Model Pembelajaran Berbasis Penstimulasian Multiple Intelligences Siswa. Jurnal Kajian Bimbingan Dan Konseling, 2(1), 1-8. https:// doi.org/10.17977/um001v2i12017p001

Legowo, E. (2017b). Model Pembelajaran Berbasis Penstimulasian Multiple Intelligences Siswa. Jurnal Kajian Bimbingan Dan Konseling, 2(1), 1-8.

Ma'rifah A, U., \& Muthmainnah, A. (2015). Metode Pembelajaran Bcct Dalam Mengembangkan Nilai Moral Pendidikan Karakter Anak Usia Dini. PG-PAUD Trunojoyo, 2(2), 117-124.

Maghfirah, E. (2020). Interview.

Nasution, N., Yaswinda, Y., \& Maulana, I. (2019). Analisis Pembelajaran Berhitung melalui Media Prisma Pintar pada Anak Usia Dini. Jurnal Obsesi : Jurnal Pendidikan Anak Usia Dini, 4(1), 240. https://doi.org/10.31004/obsesi.v4i1.311

Patintingan, M. L. (2017). Model Pembelajaran Beyond Center and Circle Times dalam Meningkatkan Kecerdasan Sosio-Emosional Anak di Paud Tumbuh Kembang Anak Makassar. PERSPEKTIF: Jurnal Pengembangan Sumber Daya Insani, 2(2), 201-207.

Rofiah, N. H. (2016). Menerapkan multiple intelligences dalam pembelajaran di sekolah dasar. Jurnal Dinamika Pendidikan Dasar, 8(1), 69-79.

Rofiq, A. (2017). Wealth Management Strategi Pengelolaan Asset:Transparansi, Akuntabilitas, Efektifitas, Efisiensi. Al-Tanzim: Jurnal Manajemen Pendidikan Islam, 1(1), 67-75.

Rohmat. (2017). Manajemen Pendidikan anak usia dini Rohmat.

Sabriye Şener, A. Ç. (2018). An Investigation between Multiple Intelligences and Learning Styles *. 6(2), 125-132. https://doi.org/10.11114/jets.v6i2.2643

Sari, P. (2019). Analisis Terhadap Kerucut Pengalaman Edgar Dale dan Keragaman Gaya Belajar untuk Memilih Media yang Tepat dalam Pembelajaran. Jurnal Manajemen Pendidikan, 1(1), 58-78.

Sary, Y. N. E. (2018). Relationship of Parenting with Child Interpersonal Intelligence in Wonokerto Village, Lumajang Regency. Jurnal Obsesi : Jurnal Pendidikan Anak Usia Dini, 2(2), 137. https:// doi.org/10.31004/obsesi.v2i2.93

Saufi, A., \& Hambali. (2019). Menggagas Perencanaan Kurikulum Menuju Sekolah Unggul. Al-Tanzim: Jurnal Manajemen Pendidikan Islam, 3(1), 29-54.

Şener, S., \& Çokçalışkan, A. (2018). An Investigation between Multiple Intelligences and Learning Styles. Journal of Education and Training Studies, 6(2), 125-132. https:// doi.org/10.11114/jets.v6i2.2643

Suharni. (2019). Manajemen Pendidikan Anak Usia Dini Pada PAUD Bintang Rabbani Pekanbaru. Jurnal Ilmiah POTENSIA, 4(1), 1-5. 
Suharti. (2018). Manajemen Pendidikan Anak Usia Dini (PAUD) dalam Rangka Meningkatkan Mutu Pembelajaran (Studi pada PAUD Negeri Pembina Curup dan PAUD Pertiwi Kabupaten Rejang Lebong). 2(1).

Tanju Gürkan, Çağlayan Dinçer, B. Ç. (2019). Integrating Multiple Intelligences into Daily Plans: A Preschool Example. 10(3), 321-345. https:// doi.org/10.17569/tojqi.515616

Trenggonowati, D. L. (2018). Analisis Faktor Optimalisasi Golden Age Anak Usia Dini Studi Kasus di Kota Cilegon. Jurnal Industrial Services, 4(1), 48-56. https://doi.org/10.36055/jiss.v4i1.4088

Wilson, S. D. (2018). Implementing Co-Creation And Multiple Intelligence Practices To Transform The Classroom Experience. Contemporary Issues in Education Research (CIER), 11(4), 127-132. https:/ / doi.org/10.19030/cier.v11i4.10206

Winarti, A., Yuanita, L., \& Nur, M. (2019). The effectiveness of multiple intelligences based teaching strategy in enhancing the multiple intelligences and Science Process Skills of junior high school students. Journal of Technology and Science Education, 9(2), 122-135. https://doi.org/10.3926/jotse.404

Yalda Delgoshaeia, N. D. (2012). Applying multiple-intelligence approach to education and analyzing its impact on cognitive development of pre-school children. 361-366. https://doi.org/10.1016/j.sbspro.2012.01.054

Yildiz, M., Öntürk, Y., \& Efek, E. (2020). The Investigation of Multiple Intelligence Modalities of University Students Receiving Sports Education. Asian Journal of Education and Training, 6(2), 246-255. https://doi.org/10.20448/journal.522.2020.62.246.255

Yuliyati, E. (2020). Pengembangan Sumber Daya Manusia Berbasis Total Quality Management Di SMK Muhammadiyah Prambanan. AL-TANZIM: Jurnal Manajemen Pendidikan Islam, 4(1), 24-35. https:/ / doi.org/10.33650/al-tanzim.v4i1.967

Zamroni, Z. (2020). Smart Parenting in Improving Students' Spiritual Intelligence in $\begin{array}{lll}\text { Pesantren-Based } \quad \text { Madrasahs. } & \text { 23(1), } a^{\prime} \text { ib }, 62 .\end{array}$ https://doi.org/10.31958/jt.v23i1.1947 